\title{
Effect of walking on roughage intake and milk yield and composition of Montbéliarde and Tarentaise dairy cows *
}

\author{
JB Coulon ${ }^{1 * *}$, P Pradel $^{2}$ \\ with the technical collaboration of E Albaret \\ ${ }^{\prime}$ Laboratoire adaptation des herbivores aux milieux, Inra, 63122 Saint-Genès-Champanelle ; \\ ${ }^{2}$ Inra, domaine expérimental de la Borie, 15190 Marcenat, France
}

(Received 11 April 1996; accepted 11 September 1996)

\begin{abstract}
Summary - Twenty-eight multiparous cows (14 Tarentaises and 14 Montbéliardes) in mid-lactation were used in a changeover design with two periods. Throughout the trial, animals received a second cut cocksfoot hay ad libitum, complemented with a fixed amount of concentrate adapted to the milk production of each animal. The first day of each of the two 8-day periods, one of the two groups (seven cows of each breed) was subjected to a single walking of $12.8 \mathrm{~km}$. During the following $24 \mathrm{~h}$, walking incurred a drop in the quantities of forage ingested $(-1.1 \mathrm{~kg}$ dry matter/day, $P<0.01)$ and in milk yield, which was greater $(P<0.05)$ in the Montbéliarde $(-3.3 \mathrm{~kg} /$ day $)$ than in the Tarentaise $(-1.7 \mathrm{~kg} /$ day $)$ cows. At the same time, fat content increased similarly in both breeds $(+6 \mathrm{~g} / \mathrm{kg}, P<0.01)$. Protein content increased only in the Montbéliarde cows $(+1.1 \mathrm{~g} / \mathrm{kg}, P<0.1)$. In both breeds, milk cell counts rose significantly after walking $(+600000$ cells $/ \mathrm{mL}, P<0.01)$, but no occurrence of clinical mastitis was observed. Walking provoked a rise in body temperature $\left(+0.5^{\circ} \mathrm{C}, P<0.01\right)$ and in nonesterified fatty acids $(+1.18 \mathrm{mM} / \mathrm{L}, P<0.01)$ and glucose $(+0.08 \mathrm{~g} / \mathrm{L}, P<0.01)$ plasma contents.
\end{abstract}

dairy cow / walking / milk yield

Résumé - Effet d'une marche prolongée sur les quantités ingérées et la production de vaches laitières Montbéliardes et Tarentaises. Au total, 28 vaches multipares (14 Tarentaises et 14 Montbéliardes) en phase descendante de lactation ont été utilisées dans un essai en inversion hiérachisé. Durant tout l'essai, les animaux recevaient à volonté un foin de dactyle de deuxième coupe, complémenté avec une quantité fixe de concentré, adaptée à la production de chaque vache. Le premier jour de chacune des deux périodes de 8 jours, un des deux lots (sept vaches de chaque race) a effec-

\footnotetext{
* This study was realized with the financial support of the "Conseil Regional d'Auvergne".

** Correspondence and reprints

Tel: 04736241 12; fax: 04736241 18; e-mail; jbc@clermont.inra.fr
} 
tué une marche prolongée unique de $12,8 \mathrm{~km}$. Au cours des 24 heures qui ont suivi la marche, on a observé une diminution des quantités ingérées de fourrage $(-1,1 \mathrm{~kg} \mathrm{MS} / j$ jour, $p<0,01)$ et de la production laitière, plus importante $(p<0,05)$ chez les vaches Montbéliardes $(-3,3 \mathrm{~kg} /$ jour $)$ que chez les vaches Tarentaises $(-1,7 \mathrm{~kg} / \mathrm{jour})$. Parallèlement, le taux butyreux a augmenté, de manière semblable chez les deux races $(+6 \mathrm{~g} / \mathrm{kg}, p<0,01)$. Le taux protéique n'a augmenté que chez les vaches Montbéliardes $(+1,1 \mathrm{~g} / \mathrm{kg}, p<0,1)$. Au sein des deux races, la numération cellulaire du lait a fortement augmenté suite à la marche $(+600000$ cellules $/ \mathrm{mL}, p<0,01)$, sans qu'aucun cas de mammite clinique ne soit détecté. La marche a entraîné une augmentation de la température corporelle $\left(+0,5^{\circ} \mathrm{C}\right.$, $p<0,01)$, et des teneurs plasmatiques en acides gras non estérifiés $(+1,18 \mathrm{mM} / \mathrm{L}, p<0,01)$ et en glucose $(+0,08 \mathrm{~g} / \mathrm{L}, p<0,01)$.

vache laitière / aptitude à la marche / production laitière

\section{INTRODUCTION}

Depending on management conditions, dairy cows are required to walk more or less long distances. When walking is restricted ( 1 to $3 \mathrm{~km} /$ day), animal performances are generally not affected (Anderson et al, 1979; Lamb et al, 1979; Gustafson et al, 1993). However, under certain conditions (scarce or hilly pasture) the distances walked by dairy cows can be substantially greater. The repercussions of walking or work on the increase of animal requirements or on production performances have been studied in sheep (Henning, 1987) and suckling cattle (Pearson and Archibald, 1989; Lawrence and Stibbards, 1990; Matthewman et al, 1993). However, little work has been done on dairy cows (Matthewman et al, 1989). In a series of recent trials (D'Hour et al, 1994; Coulon and Garel, 1996) we showed that, in animals at pasture, the response of milk yield to a long walk can vary between breeds, but we could not separate the effect of feeding level from that of animal breed. The objective of the present trial was to complete the former works, by defining, in housed animals, the effect of a long walk on the performances of Tarentaise and Montbéliarde cows, fed in such a way that their nutritive requirements were equally satisfied.

\section{MATERIALS AND METHODS}

\section{Animals and treatments}

Two groups of seven multiparous cows (mean lactation rank: 4.8) of each of the two breeds, Tarentaise and Montbéliarde, in mid-lactation (mean lactation stage at the beginning of the trial: 169 days) were used in a changeover design experiment carried out between 6 May and 2 June 1995. They were housed in individual stalls. At the beginning of the trial, milk yield was 16.8 and $12.4 \mathrm{~kg} /$ day for the Montbéliarde and Tarentaise cows, respectively (table I). Throughout the trial, all animals were fed a diet composed of a second cut of cocksfoot hay (0.81 UFL, $77 \mathrm{~g}$ PDIN and $85 \mathrm{~g}$ PDIE per kg dry matter $[D M]$ ), provided ad libitum, and of a production-type concentrate (1.05 UFL, $127 \mathrm{~g}$ PDIN and $127 \mathrm{~g}$ PDIE per $\mathrm{kg} \mathrm{DM}$ ), the quantities of which were fixed for the duration of the trial according to the milk yield observed during the 2 weeks preceding the beginning of the trial (ie, $0,1,2,3$ and $4 \mathrm{~kg} /$ day for milk yields of 14,16 , 18,20 and $22 \mathrm{~kg} /$ day of fat-corrected milk). On average, Montbéliarde cows received $2.1 \mathrm{~kg}$ $\mathrm{DM} /$ day of concentrate and Tarentaise cows $0.7 \mathrm{~kg} \mathrm{DM} / \mathrm{day}$. Additionally, all animals received $100 \mathrm{~g} /$ day of mineral supplement $(6 \mathrm{P}$ $14 \mathrm{Ca}$ ). Hay was fed in two daily meals and concentrate in one meal, unless quantities exceeded $3 \mathrm{~kg} /$ day, which were fed in a second meal. In a first 10-day period (P0), all animals were managed in the same way. On the first day of a second 8-day period (P1), one group walked $12.8 \mathrm{~km}$ ( $3.2 \mathrm{~km}$ circuit, with a total elevation variation of $80 \mathrm{~m}$, covered four times), after the morning milking, according to the procedures defined by 
Table I. Milk production, food intake, blood parameters and behaviour data.

\begin{tabular}{|c|c|c|c|c|c|c|c|}
\hline & \multicolumn{2}{|c|}{ Tarentaise } & \multicolumn{2}{|c|}{ Montbéliarde } & \multirow[t]{2}{*}{$R S D^{1}$} & \multicolumn{2}{|c|}{ Significance } \\
\hline & Rest & Walking & Rest & Walking & & $T R$ & $T R \times B R$ \\
\hline \multicolumn{8}{|l|}{ Week before walking } \\
\hline Live weight $(\mathrm{kg})$ & 593 & 595 & 637 & 637 & & & \\
\hline Milk yield (kg/day) & 12.5 & 12.2 & 16.8 & 16.7 & & & \\
\hline Energy balance (UFL/day) & 1.1 & 1.2 & 1.4 & 2.0 & & & \\
\hline \multicolumn{8}{|l|}{ Walking day ${ }^{2}$} \\
\hline Hay intake (kg DM/day) & 12.4 & 11.3 & 14.7 & 13.6 & 1.5 & $* *$ & NS \\
\hline Milk yield (kg/day) & 12.0 & 10.3 & 17.1 & 13.8 & 1.2 & $* *$ & $*$ \\
\hline Fat concentration $(\mathrm{g} / \mathrm{kg})$ & 37.7 & 43.2 & 38.0 & 44.6 & 4.2 & $* *$ & NS \\
\hline Protein concentration $(\mathrm{g} / \mathrm{kg})$ & 33.1 & 32.9 & 33.1 & 34.2 & 1.2 & NS & + \\
\hline Fat yield (g/day) & 446 & 439 & 645 & 605 & 60 & NS & NS \\
\hline Protein yield (g/day) & 398 & 337 & 563 & 469 & 44 & $* *$ & NS \\
\hline Somatic cell count $(\log / m L)$ & 5.29 & 5.78 & 5.19 & 5.80 & 0.28 & $* *$ & NS \\
\hline Energy supply (UFL/day) & 10.8 & 9.9 & 14.0 & 13.1 & 1.2 & $* *$ & NS \\
\hline $\begin{array}{l}\text { Estimated energy balance } \\
\text { (UFL/day) }\end{array}$ & 0.8 & 0.2 & 1.5 & 1.4 & 1.3 & NS & NS \\
\hline $\begin{array}{l}\text { Estimated nitrogen balance } \\
\text { (g PDI/day) }\end{array}$ & 105 & 60 & 186 & 198 & 129 & NS & NS \\
\hline Time spent lying ${ }^{3}(\min )$ & 172 & 150 & 157 & 154 & 29 & NS & NS \\
\hline Time spent eating ${ }^{3}(\mathrm{~min})$ & 180 & 123 & 200 & 129 & 25 & $* *$ & NS \\
\hline Time spent lying ${ }^{4}(\min )$ & 143 & 150 & 132 & 154 & 24 & $*$ & NS \\
\hline Time spent eating ${ }^{4}(\min )$ & 113 & 123 & 114 & 129 & 21 & $*$ & NS \\
\hline Body temperature $\left({ }^{\circ} \mathrm{C}\right)$ & 38.3 & 38.8 & 38.3 & 38,9 & 0.3 & $* *$ & NS \\
\hline Glucose $(\mathrm{g} / \mathrm{L})$ & 0.63 & 0.66 & 0.60 & 0,72 & 0.07 & $* *$ & $*$ \\
\hline $\mathrm{NEFA}(\mu \mathrm{M} / \mathrm{L})$ & 100 & 1370 & 70 & 1150 & 250 & $* *$ & NS \\
\hline \multicolumn{8}{|l|}{ Days 2 to 5 after walking } \\
\hline Hay intake (kg DM/day) & 12.7 & 12.6 & 14.6 & 14.1 & 1.0 & NS & NS \\
\hline Milk yield (kg/day) & 12.1 & 12.0 & 16.6 & 16.5 & 0.6 & NS & NS \\
\hline Fat concentration $(\mathrm{g} / \mathrm{kg})$ & 35.8 & 37.9 & 37.1 & 38.4 & 3.5 & + & NS \\
\hline Protein concentration $(\mathrm{g} / \mathrm{kg})$ & 32.3 & 32.5 & 33.0 & 33.1 & 0.5 & NS & NS \\
\hline Somatic cell count $(\log / m L)$ & 5.26 & 5.41 & 5.21 & 5.41 & 0.23 & $*$ & NS \\
\hline
\end{tabular}

${ }^{\mathrm{I}}$ Residual standard deviation; ${ }^{2}$ performances during the $24 \mathrm{~h}$ after walking; ${ }^{3}$ Between the end of the morning milking and the beginning of the evening milking; ${ }^{4}$ between the end of walking and the beginning of the evening milking. TR: treatment; BR: breed; NEFA: non-esterified fatty acids. $+P<0.1 ; * P<0.05 ; * * P<0.01$; NS: not significant. 
D'Hour et al (1994). The other group remained in the stable with free access to hay. Eight days later (P2), the treatments were inversed. Each walking lasted about $3 \mathrm{~h}$.

\section{Measurements}

Milk yield was individually weighed at each milking. Milk chemical composition (fat and protein contents) and cell counts were analysed at each milking, each day throughout periods $\mathrm{P} 1$ and $\mathrm{P} 2$ and for the 7 last days of period $\mathrm{P} 0$. The quantities of feed ingested were measured individually each day. On walking days, refusals were measured twice daily (16.00 and 07.00 hours), to assess the quantities of feed taken during the first hours following the return of the animals to the stable ( 10.30 hours). DM content of the foods was determined every day for hay and once a week for concentrate. The chemical composition of the hay was determined once in the course of the trial. The DM and organic matter digestibilities of the hay were determined using six wether sheep during a 1-week measurement period after a 2-week adaptation period. Their nutritional value was computed according to the Inra equations as established by Andrieu and Demarquilly (1987). The quantities of water consumed were measured, per group, every day and every $2 \mathrm{~h}$ on walking days. Also on walking days, as soon as the animals returned to the stable, body temperature was measured and a blood sample was taken from all cows. Two tubes of plasma were prepared and frozen for analysis of glucose (Bergmeyer et al, 1974) and non-esterified fatty acid (NEFA) contents (Chilliard et al, 1984). On these same days, the behaviour of the animals (eating, standing or lying) was observed visually every $5 \mathrm{~min}$, between the two milkings for the rest group and between their return to the stable (10.30 hours) and the evening milking (16.00 hours) for the walking group.

\section{Data analysis}

The immediate effect of walking was assessed by considering, on the one hand, animal performances during the $24 \mathrm{~h}$ after walking (ie, corresponding to the two milkings following walking) and, on the other hand, over the following 4 days (days 2 to 5 after walking). These data were treated by analysis of variance (GLM pro- cedure, SAS, 1987). Fixed effects included in the model were treatment, breed, treatment $x$ breed interaction, period, period $\times$ breed interaction and cow (nested within breed). Milk cell count was expressed as a logarithm. The values presented in figure 1 are arithmetic means. For behaviour variables, times spent eating, ruminating, lying or standing, were calculated either over the time separating the two milkings of walking days, or over the time between the return to the stable of walking animals and the evening
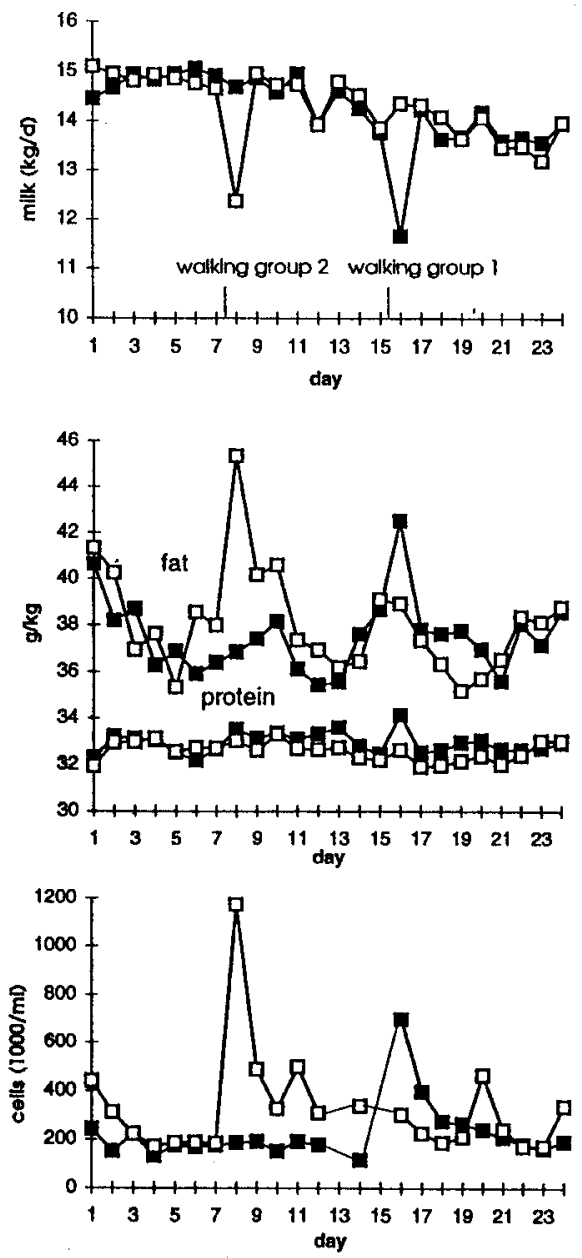

Fig 1. Milk production and composition pattern during the trial.(ロ: group 1; $\square$ : group 2). 
milking. For these data, as for body temperature and blood parameters, the treatment model was the same as that described earlier.

\section{RESULTS}

The walk caused a considerable decrease in milk yield over the two subsequent milkings $(2.5 \mathrm{~kg}, P<0.01)$. This drop was significantly greater in Montbéliarde than in Tarentaise cows $(3.3$ vs $1.7 \mathrm{~kg}, P<0.05)$ (table I). It was equally spread over the two milkings following walking (respectively -1.2 and $-1.3 \mathrm{~kg}$ in the two subsequent milkings) but, regardless of breeds, did not persist beyond the first day (fig 1). Within breed, the depression of yield was neither linked to the production level of animals nor to their live weight (fig 2). Fat content increased similarly in both breeds $(+6 \mathrm{~g} / \mathrm{kg}$, $P<0.01)$. Protein content did not vary in Tarentaises cows and slightly increased in Montbéliarde cows $(+1.1 \mathrm{~g} / \mathrm{kg}, P<0.1)$. Consequently, fat yields were not affected by walking, contrary to those of protein $(-78 \mathrm{~g} /$ day, $P<0.01)$. Whatever the breed, milk yield and hay intake were similar in the two groups during days 2 to 5 after walking (table I). However, fat concentration remained slightly higher $(P<0.1)$ in cows having walked, compared to those at rest.

In both breeds, milk cell counts increased considerably in the two milkings subsequent to walking (nearly 600000 cell $/ \mathrm{mL}$ in arithmetic mean, $P<0.01$ ), but no occurrence of clinical mastitis was observed. This increase concerned all animals, but varied widely in amplitude: in nine cows it was below 200000 cells $/ \mathrm{mL}$, and in six cows it exceeded 1000000 cells $/ \mathrm{mL}$. This increase was linked neither to the initial level of cells in milk, nor to the extent of the decrease in milk yield. It was, on average, more significant in the first period than in the second, probably due to harsher weather conditions in the first period (mean temperature $5.1^{\circ} \mathrm{C}$ vs $11.9^{\circ} \mathrm{C}$ in the second period). The cell counts of animals having walked remained above those of control animals for 4 days $(+100000$ cells $/ \mathrm{mL}$ during days 2 to 5 after walking, $P<0.05$ ), especially in the first period (fig 1).

On the day of walking, the quantities of forage ingested until the evening milking were reduced by $2.4 \mathrm{~kg} \mathrm{DM}$. Part of this difference was made up for during the night, so that by the next morning the remaining difference between the two groups was only $1.1 \mathrm{~kg}$ DM $(P<0.01)$, whatever the breed, which incurred a decline in energy supply of 0.9 UFL (table I). The quantities of water drunk, respectively equal to 80 and 92 L/cow/day in Tarentaise and Montbéliarde
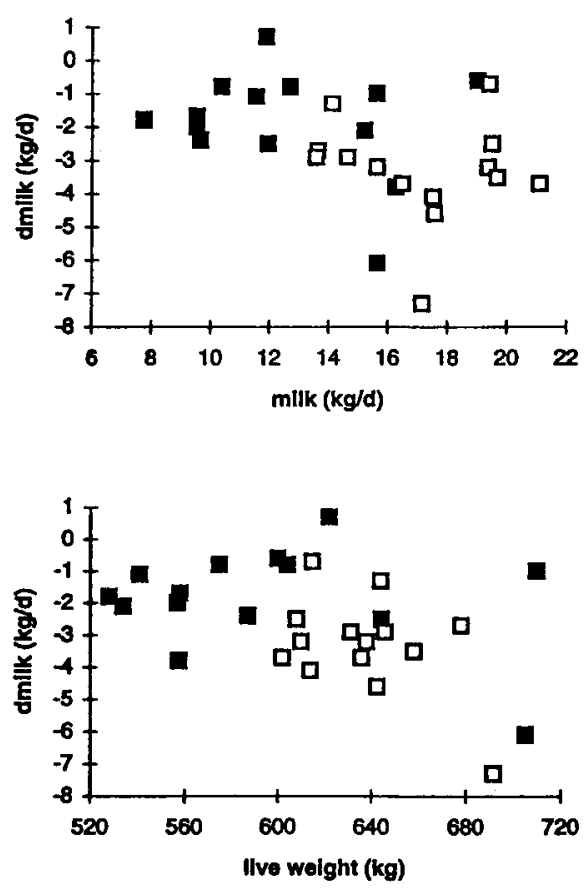

Fig 2. Relationship between the effect of walking on milk yield (dmilk), once corrected for period effect (upper graph), and milk yield and live weight at the beginning of the trial (lower graph). ( $\square$ : Tarentaise cows; $\square$ : Montbéliarde cows). 
cows on the days preceding the walk, remained unchanged on walking days.

On walking days, cows having walked spent, once in the stable, 13 min longer feeding than those having remained in the stable $(P<0.05)$. Between the two milkings, the latter spent $61 \mathrm{~min}$ more taking feed than those having walked $(P<0.01)$. The forage intake rate was not modified by walking (respectively, 45 and $48 \mathrm{~g} \mathrm{DM} / \mathrm{min}$ for cows at rest and those having walked). Between the two milkings, time spent lying did not differ between treatments.

Walking incurred a significant rise in body temperature $\left(+0.5^{\circ} \mathrm{C}, P<0.01\right)$, as well as an increase in NEFA $(+1.18 \mathrm{mM} / \mathrm{L}$, $P<0.01)$ and glucose $(+0.08 \mathrm{~g} / \mathrm{L}, P<0.01)$ plasma contents. The increase in glucose content was more marked $(P<0.05)$ in Montbéliarde $(+0.12 \mathrm{~g} / \mathrm{L})$ than in Tarentaise cows $(+0.03 \mathrm{~g} / \mathrm{L})($ table I).

\section{DISCUSSION}

This trial confirmed that a long walk incurs a considerable decrease in milk yield, but of very short duration (two milkings). However, animals were fed above their requirements (the energy balance during the 4 days before walking was, indeed, largely positive: + $1.4 \mathrm{UFL} /$ day on average) and therefore, in all probability, were less sensitive to extreme variations in nutritive supply. The concomitant variations in fat content were linked to the concentration of the fat yielded, as often observed upon extreme fluctuations in feed supply (Stobbs and Brett, 1974). The animal mobilizes its body reserves to synthesize milk fats which are concentrated in a smaller volume. The drop in milk yield far exceeded that which we observed previously at pasture, for animals of the same breed submitted to the same physical effort (D'Hour et al, 1994). This difference could be partly due to the fact that, in the present study, animals were not trained for walking (before the beginning of the trial, the only exercise taken by cows was the walk between their stall and the milking parlour, ie, around $200 \mathrm{~m}$ per day). The increase in energy requirements linked to walking can be assessed, according to the data of Ribiero et al (1977) and considering the nature of the circuit, at around $4500 \mathrm{kcal}$ of metabolizable energy, ie, 1.6 UFL (if we assume an efficiency of metabolizable energy utilization for lactation of 0.6 ). As observed by Matthewman et al (1993), this increase in energy requirements was not compensated for by an increase in forage intake. On the contrary, cows having walked ingested less forage than cows at rest, due to the reduced access time, compensated for neither by an increased rate of intake nor by a sufficiently raised nocturnal intake. Fatigue engendered by the walk may be responsible for this difference: Metz (1984) demonstrated that dairy cows required a minimum amount of rest during the day. Overall, the effect of walking resulted in a difference of $2.5 \mathrm{UFL}$ between cows at rest and those having walked (1.6 UFL due to the increase of energy requirements (see earlier) plus 0.9 UFL due to lower energy supply (table I)). This would correspond to $5.7 \mathrm{~kg}$ of milk with a $4 \%$ fat content if we consider a maximal marginal efficiency of $2.3 \mathrm{~kg} / \mathrm{UFL}$. However, cows responded far less than this theoretical value because of their ability to rapidly and strongly mobilize their body reserves, as indicated by the extremely high increase in NEFA plasma content just after walking (Matthewman et al, 1989; Pearson and Archibald, 1989; D'Hour et al, 1994; Animut and Chandler, 1996).

As observed earlier (D'Hour et al, 1994; Coulon and Garel, 1996), the response of milk yield to walking differed between breeds. Contrary to those trials, however, we cannot propose a difference in energy balance (during the days preceding walking, Montbéliarde and Tarentaise cows all had a positive energy balance: respectively, +1.5 and $+1.0 \mathrm{UFL} /$ day). This disparity 
could be due to morphological differences which allow Tarentaise cows to expend less energy when walking; their weight is slightly below that of Montbéliarde cows $(-40 \mathrm{~kg})$, but it does not seem that live weight per se was responsible for the variation of milk yield response to walking (fig 2). It is also possible that Tarentaise cows are able to better counteract an important energy shock. The greater increase in glucose content in Montbéliarde cows immediately after the physical effort supports this argument. Indeed, as was observed previously in cows (D'Hour et al, 1994) and ewes (Animut and Chandler, 1996), glucose content was raised just after walking, in all likelihood due to increased muscular requirements (Pearson and Archibald, 1989).

This trial emphasized a considerable increase in milk cell counts subsequent to walking. Due to the lack of information surrounding the characteristics of the cells excreted and the possible presence of pathogenic germs in the milk, this result is difficult to interpret. Substantial increases in cell counts have occasionally been observed in the absence of mammary infection, consecutive to thermal or drug treatment stress (Wegner et al, 1976). These results are, however, disputed (Paape et al, 1973). The indirect effect of concentration linked to the depressed milk yield can only explain a small part of this result, all the more so that we observed no inter-individual relationship between the decrease in milk yield and the increase in cell counts. It is more probable that a long walk undergone without prior training resulted in physical mammary traumas, which were responsible for the raised milk cell counts. These traumas could have been accentuated by weather conditions, as would indicate the wide difference in response between the two periods.

The practical consequences of these results (drop in milk yield varying according to breed, effect on cell count) can be con- siderable, particularly in cows managed, during pasture, in an extensive system. These initial observations must, however, be clarified by trials in which walking is repeated over a long time span.

\section{REFERENCES}

Anderson MJ, Lamb RC, Walters JL (1979) Effect of prepartum exercise on feed intake and milk production of multiparous cows. J Dairy Sci 62, 14201423

Andrieu J, Demarquilly C (1987) Valeur nutritive des fourrages : tables et prévisions. Bull Tech CRZV Theit, INRA 70,61-73

Animut G, Chandler KD (1996) Effects of exercise on mammary metabolism in the lactating ewe. Small Rum Res 20, 205-214

Bergmeyer HU, Bernt E, Scmith F, Stork H (1974) DGlucose determination with hexokinase and glucose-6-phosphate-deshydrogenase. In: Methods of Enrymatic Analysis (Bergmeyer HU, ed) Academic Press. London, vol 3, 1196

Chilliard Y, Bauchart D, Barnouin J (1984) Determination of plasma non-esterified fatty acids in herbivores and man: a comparison of values obtained by manual or automatic chromatographic, titrimetric, colorimetric and enzymatic methods. Reprod Nur Dev 24, 469-482

Coulon JB, Garcl JP (1996) Aptitude à la marche de vaches Jaitières de types génétiques différents : inlluence d'un exercice répété sur la production laitière. Ann Zootech 45, 349-355

D'Hour P, Hauwuy A, Coulon JB, Garel JP (1994) Walking and dairy cattle performance. Arm Zootech 43, 369-378

Gustafson GM. Luthman J, Burstedt E (1993) Effect of daily exercise on performance, feed efficiency and energy balance of tied dairy cows. Ac'ta Agric Scand 43, $219-227$

Henning $\mathrm{PH}$ (1987) The effect of increased energy demand through walking exercise on intake and ruminal characteristics of sheep fed a roughage diet. I Agric Sci (Camb) 109, 53-59

Lamb RC, Barker BO, Anderson MJ, Walters JL ( 1979) Effects of forced exercise on two-year-old Holstein heifers. J Dairy Sci 62, 1791-1797

Lawrence PR, Stibbards RJ (1990) The energy cost of walking, carrying and pulling loads on flat surfaces by brahman cattle and swamp buffalo. Anim Prod 50, 29-39

Mathewman RW. Merritt J, Smith AJ, Phillips P, Oldham JD (1989) Effects of exercise on lactational performance in cattle. Proc Nutr Soc 92A

Matthewman RW, Oldham JD, Horgan GW (1993) A note on the effect of sustained exercise on straw 
intake and body weight in lactating cattle. Anim Prod 57, 491-494

Metz JHM (1984) The reaction of cows to a short-term deprivation of lying. Appl Anim Behav $S_{c i} 13,301$. 307

Paape MJ, Kral AJ, Desjardins C, Schultze WD, Miller RH (1973) Failure or either corticosteroids or ACTH to increase the leucocyte concentration in milk. Am J Vet Res 34, 353-356

Pearson RA, Archibald RF (1989) Biochemical and haematological changes associated with short periods of work in draught oxen. Anim Prod 48, 375 384
Ribiero JM, Brockway JM, Webster AJF (1977) A note on the energy cost of walking in cattle. Anim Prod 25, 107-110

Statistical Analysis Systems Institute (1987) SAS User's Guide: Statistics. SAS Institute Inc, Cary, NC, USA

Stobbs TH, Brett DJ (1974) Milk yield and composition of milk and blood as indicators of energy intake by Jersey cows. Aust J Agric Res 25, 657-666

Wegner TN, Schuh JD, Nelson FE, Stott GH (1976) Effect of stress on blood leucocyte and milk somatic cell counts in dairy cows. J Dairy Sci $59,949-956$ 